\title{
Commentaries
}

\section{The Life Cycle of a British Islamist: A Jungian Perspective}

\author{
Lawrence Alschuler*a \\ [a] Professor of Political Science (retired 2001), Department of Political Science, University of Ottawa, Ottawa, Canada.
}

Journal of Social and Political Psychology, 2014, Vol. 2(1), 31-42, doi:10.5964/jspp.v2i1.272

Received: 2013-10-07. Accepted: 2014-01-28. Published (VoR): 2014-02-21.

Handling Editor: J. Christopher Cohrs, School of Humanities and Social Sciences, Jacobs University Bremen, Bremen, Germany

*Corresponding author at: Route de Van 22, 1922 Salvan, Switzerland. E-mail: lafre@bluewin.ch

This is an open access article distributed under the terms of the Creative Commons Attribution License

(http://creativecommons.org/licenses/by/3.0), which permits unrestricted use, distribution, and reproduction in any medium, provided the original work is properly cited.

When the media report that Islamists have made a terrorist attack or a suicide bombing we might wonder whether this is the destiny of Islamists. We know that the vast majority of Muslims are not Islamists and we ought to realize that only a few Islamists ever become terrorists. Why would an Islamist choose the path of violence or renounce that path? What might lead him to fanaticism rather than moderate political activism? Could there be a life cycle in the experience of an Islamist? These questions led me to write this article. Having had a career as a political scientist and training in Jungian analysis it is natural that I would seek answers by combining these two fields. It was only after leaving the training program at the C. G. Jung Institute-Zurich, that I began to find connections between what I had learned there and my political concern for understanding and combatting oppression. Specifically, I wanted to know why the oppressed so seldom revolted against their oppressors in the history of Latin America. The Jungian theory of complexes, along with other Jungian ideas, was a key to understanding the mind of the oppressed and the development of their political consciousness. The study of autobiographies of Native persons, two in Guatemala and two in Canada, revealed the richness of a Jungian psychopolitical framework to understand oppression (Alschuler, 2007). Wanting to extend the scope of my study, from Native persons to another context, I came upon the autobiography of an Islamist on which I could try out my ideas. The results of this new study were gratifying (Alschuler, 2011). The present study draws on a distincly different Jungian framework to restudy the same case.

A recent re-reading of Edward Edinger's (1973) Ego and Archetype suggested some answers to my questions about Islamism, even though he never had Islamism in mind when he wrote the book. In order to see how well his ideas would apply to the experience of an Islamist, I re-analyzed the autobiography of a British-born Muslim. Those ideas did indeed fit the case very well as I will demonstrate in this article. It is first necessary to spell out clearly Edinger's relevant ideas on the religious function and secondly to apply them critically to the case at hand. 
The loss of a meaningful connection to a religious tradition, under favorable conditions, may be followed by a reconnection to a source of spirituality. Along the way, however, a substitute secular movement may respond to the spiritual needs of the person. This is what Edward Edinger, a Jungian analyst, calls "unconscious religion". C. G. Jung believes that the individual needs to feel related to a supra-personal force, usually called "god". Jung calls this the "religious function" (Jung, 1968, para. 14, p. 12). If this need is not met by an organized religion, the psyche seeks an alternative because the function itself cannot be eliminated.

In his book, Ego and Archetype: Individuation and the Religious Function of the Psyche, Edinger uses the term, "unconscious religion", to designate such an alternative. This may be the psychological role played by political movements when religious institutions cease to provide containers for the spiritual strivings of individuals (Edinger, 1973, p. 68). Political movements include, for instance, communism, socialism, colonial independence, fascism, Nazism, and more recently, environmentalism, feminism, anti-globalization. I include Islamism, also called "political Islam", as a political movement.

In the Muslim world, the fusing of religion and nationalism is called 'Islamism.' Developed primarily in postcolonial Egypt and India, Islamism is a political philosophy that seeks to establish an Islamic state-either through grassroots social and political activism or through violent revolution—built upon a distinctly Islamic moral framework (Aslan, 2010, p. 23).

Aslan considers Islamism to be a political ideology of Islamic religious nationalism (Aslan, 2010, p. 180). He distinguishes Islamism as a political ideology from Islam as a faith. Aspects of Islamism include: enforcement of sharia law, pan-Islamic political unity, elimination of non-Muslim political, military, economic, social, or cultural influences on the Muslim world. If Islamism is a political movement, not a religion, it may yet be an "unconscious religion", in the words of Edinger.

In a recent autobiography, a young British-born Muslim tells of his transition from being a traditional Muslim, to a fanatical Islamist, and finally to a spiritual Muslim. Ed Husain's (2007) narrative, The Islamist: Why I Joined Radical Islam in Britain, What I Saw Inside and Why I Left, has become a focus for discussion on how British-born Muslims could have perpetrated the 7/7 terrorist attacks in London in 2005. Edinger's description of unconscious religion closely resembles Husain's phase of fanatical Islamism. After summarizing Edinger's ideas I will present the case of Ed Husain.

"Fanaticism" takes on a specific meaning within the scope of Jungian psychology and relies on two key processes, repression and projection. Repression is the process by which the psyche protects the ego, making unconscious any beliefs that are incompatible with one's self-image. Projection is the counterpart of repression, a process that brings to consciousness beliefs that belong to the ego. Only now, these appear to belong to "others" who carry the projections. The excessive zeal for some belief, characterizing fanaticism, derives from a psychodynamic process that begins with repressed doubt (Jung, 1990, p. 15). I condense this process into a vicious circle of fanaticism (Alschuler, 2009). One sustains an extreme belief by repressing into the unconscious any doubts about its truth. Repressed doubts do not lie dormant but rather "seek" consciousness by being projected onto those who embody the doubt, namely those who oppose the beliefs. The fanatic, one who holds the beliefs, then feels threatened by those opponents who express his repressed doubts. In order to defend his beliefs against doubt, the fanatic feels compelled to convert or to eliminate the opponents. In the final phase of this process, the elimination or conversion of opponents reinforces the fanatic's beliefs because one concludes that they were inferior 
or convinced. However, the viscious circle continues because the further repression of doubts brings about projection onto opponents and so on (Alschuler, 2009, p. 65).

\section{Edinger's Views on the Failure of Religious Institutions and the Rise of "Unconscious Religion"}

Edinger employs a set of concepts to articulate his model of the psyche: ego, Self, ego-Self axis, and individuation. These concepts require clarification in order to understand his views on unconscious religion. For him the entire psyche consists of consciousness and the unconscious. The ego is the center of consciousness, the locus of bodily sensations, time and space, memory, and the self-image. The Self (capital $S$ ) is the center of the entire psyche, of both consciousness and the unconscious. The Self gives the ego strength, durability, and meaning and guides the ego toward individuation. The ego-Self axis is the dynamic channel of communication between the ego and the Self, exemplified by dreams from the Self and prayers from the ego. Individuation is the life-long process in which the ego moves toward wholeness by making more and more repressed elements conscious. In this process the ego becomes partially conscious of the ego-Self axis and accepts the subordination of the ego to the Self, the image of the deity in the psyche (Edinger, 1973, pp. 3-7).

Inspired by ideas of C. G. Jung (1990, pp. 15-17; 1938, pp. 104-105), Edinger offers his own views on unconscious religion. Jung's ideas begin with deploring the socialist dictatorial State for usurping the role of religious institutions and becoming sanctified in the mind of the masses as a substitute vehicle for religious aspirations. To paraphrase Jung, in the mind of the masses the State takes the place of God, State policies are creeds, the leader is a demigod, his votaries are apostles, and disbelievers of the "one truth" are heretics. The parade of State power replaces ecclesiastical processions to ward off demons and to give the masses a feeling of security. The State, like the Church, demands self-sacrifice and devotion. Both the State and the Church ensure that their demands be met: the State by terror; the Church by the "fear of God" (Jung, 1990, pp. 15-16).

Edinger, in contrast, coins the term, "unconscious religion", to understand the role of social and political movements when religious institutions fail to respond to popular spiritual needs.

When the collective psyche is in a stable state, the vast majority of individuals share a common living myth or deity. Each individual projects his inner God-image (the Self) to the religion of the community. The collective religion then serves as the container of the Self for a multitude of individuals... As long as it is functioning adequately, the church protects the society against any widespread inflation or alienation. (Edinger, 1973, p. 65)

The fact is that large numbers of individuals do not have living, functioning, suprapersonal categories by which they can understand life experience, supplied either by the church or otherwise. This is a dangerous state of affairs because, when such categories do not exist, the ego is likely to think of itself as everything or nothing (Edinger, 1973, p. 64). [Here "everything" means inflation; "nothing" means alienation; see definitions below.] ... Furthermore, when the archetypes have no adequate container such as an established religious structure, they have to go somewhere else because the archetypes are facts of psychic life. One possibility is that they will be projected into banal or secular matters. (Edinger, 1973, p. 64) 
Personal, secular, or political actions become charged with unconscious religious meaning. This is particularly dangerous because whenever a religious motivation is acting unconsciously it causes fanaticism with all its destructive consequences. (Edinger, 1973, p. 65, italics mine)

Something happens in the individual psyche when "the outer church loses its capacity to carry the projection of the Self ... All the psychic energy and values that had been contained in the church now flow back to the individual, activating his psyche and causing serious problems" (Edinger, 1973, p. 65). According to Edinger, the loss of a projected religious value has four possible consequences:

1. The projected supra-personal value which has been withdrawn from its religious container will be reprojected onto some secular or political movement... When religious energy is applied to a secular object we have what can be described as idolization-which is a spurious, unconscious religion. (p. 68, italics mine)

2. The individual may take on himself, on his own ego and personal capacities, all the energy previously attached to deity. Such a person succumbs to inflation (italics mine). Examples of this are seen in the hybris that over-values man's rational and manipulative powers and denies the sacred mystery inherent in life and nature. (pp. 65-68)

3. With the loss of the god-projection into the church, the individual will at the same time lose his inner connection with the Self. The individual then succumbs to alienation and all the symptoms of the empty meaningless life that are so common today. (p. 65, italics mine)

4. If when the individual is thrown back on himself through the loss of a projected religious value, he is able to confront the ultimate questions of life that are posed for him, he may be able to use this opportunity for a decisive development in consciousness (italics mine)... he may discover the lost value, the god-image, within the psyche... The connection between ego and Self is now consciously realized. In this case the loss of a religious projection has served a salutary purpose; it has been the stimulus which leads to the development of an individuated personality. (p. 68)

I believe that Ed Husain experienced all four of these possibilities in sequence! Before documenting my view by quotations from Husain, I will to give a brief biography to place his experience in context.

\section{Biographical Sketch of Ed Husain}

Ed Husain was born in 1974 in Mile End, United Kingdom. Husain describes himself as British by birth, Asian by descent, and Muslim by conviction. Both parents immigrated to Britain from Pakistan. Of modest income, the father works as a restaurateur. Ed's education began in London's East End and continued at Stepney Green School, attended mostly by immigrant boys from Bangladesh, with a reputation for Muslim gang rivalries. At age fourteen he accompanied a Muslim spiritual guide, a friend of his family, on trips throughout England in the summers of 1989 and 1990.

\section{Abandoning Traditional Islam for Moderate Islamism}

At age sixteen Ed is introduced to moderate Islamist activities of the Jamet-e-Islami, centered at the East London mosque. He renounces his parents' traditional Islam to dedicate himself to political Islam. While a student at Tower Hamlets College he becomes president of the Islamic Society.

\section{Turning to Fanatical Islamism}

Two years later he becomes disappointed with moderate Islamism and joins the radical Hizb ut-Tahrir. As an activist he recruits new members and debates with moderate Islamist organizations. 


\section{Returning to Moderate Islamism}

At the end of these five years, Husain becomes disillusioned with the extremist views of the Hizb and rejects the climate of violence engendered by the Hizb. Having discontinued his Islamist activism he remains identified with radical Islamism, though doubtful of its many political promises.

\section{Searching for Spiritual Islam}

By 2000 Husain is finally ready to renounce Islamism altogether and begins a search for spiritual Islam. He finds support from his new bride, Faye, of a similar ethnic background. Together they make plans to study Arabic and seek a spiritual Islam. In 2002 they go to Damascus, Syria for their studies and support themselves by teaching English under the British Council. In 2005 they begin a seven-month stay in Jeddah, Saudi Arabia for further studies of Arabic and the Koran while teaching English under the British Council. These travel experiences enable him to find the spiritual Islam he sought and to renew his identity as a proud British Muslim now living in Britain.

\section{Case Study of Ed Husain and Edinger's Four Possibilities}

In each part of this case study I will first $\mathbf{A}$. recall the relevant idea of Edinger, then B. define key concepts, and finally C. support Edinger's idea with quotations from Husain.

\section{Unconscious Religion, the First Possibility}

\section{A. Edinger's idea}

"The projected supra-personal value which has been withdrawn from its religious container will be reprojected onto some secular or political movement" (Edinger, 1973, p. 68). That movement becomes an unconscious religion.

\section{B. Definition of projection}

"Thus Jung defined projection as an unconscious, that is, unperceived and unintentional, transfer of subjective psychic elements onto an outer object" (von Franz, 1985, p. 3). Projection is the transfer of images from a person's psyche onto an outer object that takes place unconsciously, unintentionally, and unperceived.

\section{Quotations}

Husain's commitment to political Islam includes a "reverence" for Islamist doctrines and leaders. Fanatical adherence to Islamism becomes an unconscious religion. Husain derives from Islamic scriptures the rudiments of a political system and a total ideology to solve all the world's problems. This commitment expresses his quasi-religious sentiment, though applied to a political movement, Islamism.

"I was considered part of the Islamic movement", an active member of the YMO (Husain, 2007, p. 37) (Young Muslims Organization, an Islamist group at the East London mosque). "For deep down I had committed myself, my life, to the Islamist movement and, like my brothers at the mosque, I would let nothing stand in the way of following Islam as a complete life code" (p. 42). At Tower Hamlets College, as elected President of the Islamic Society, a front organization for political Islamism, he espouses the following "truths": good is equated with Islam and its "true" Muslims, while evil with the West, and "partial" Muslims, those who serve as agents of Western imperialism (pp. 36, 48, 49, 51). "Islam was the solution for all the world's ills" (p. 54). He deepens his commitment and becomes receptive to the appeal of Omar Bakri, a Syrian-born Muslim cleric, and the Hizb ut-Tahrir, which sponsor the 
restoration of the caliphate, an Islamic state. This charismatic leader embodies all the answers and represents a "true" Muslim. "The Muslim nation was a global nation, and we had a religious obligation to establish a global state that would rival the United States and Europe" (p. 88). The Prophet had "bequeathed a political system for us to implement, a total ideology for global domination: Islam" (p. 93).

\section{Inflation, the Second Possibility}

\section{A. Edinger's idea}

"The individual may take on himself, on his own ego and personal capacities, all the energy previously attached to deity. Such as person succumbs to inflation" (Edinger, 1973, p. 65).

\section{B. Definition of inflation}

"It is a state in which something small (the ego) has arrogated to itself the qualities of something larger (the Self) and hence is blown up beyond the limits of its proper size" (Edinger, 1973, p. 7). "Intellectual rigidity which attempts to equate its own private truth or opinion with universal truth is also inflation" (p. 15). In other words, inflation is the psychic condition resulting from an ego that has taken on qualities of something greater and becomes blown up beyond its normal size. To consider one's own opinion as a universal truth is also inflation.

\section{Quotations}

Husain's pride in Islamism and his sense of Muslim superiority lead him fanatically to defend the Islamist doctrine as if it were a faith, by debating with Muslim students, leading Islamist organizations, and converting ordinary Muslims. His fanaticism corresponds to Jung's treatment of the subject (Alschuler, 2009).

Husain avidly reads books by Islamist ideologues and becomes inflated: "Now I was not a mere Muslim, like all the others I knew; I was better, superior" (Husain, 2007, p. 36). His reading allows him to distinguish between categories of Muslims: "true" Muslims, whose ideologies are all shaped by Islam, and "partial" Muslims, who confine their religion to prayer and piety (p. 37). In 1995 he extends his fanatical beliefs even further to include non-Muslims as well as "partial" Muslims. "As an Islamist, I saw everyone along religious lines, and all non-Muslims as inferior to us" (p. 130). Back at college in Newham, Husain has classmates of different ethnicities and nationalities: non-Muslim British, Africans, Asians, Christians, Sikhs, Hindus, and ordinary Muslims. For him, these students were divided into two groups, Muslims and the rest. "We were Muslims, superior and different from others" ( $p$. 142). He seeks to convince Muslims of different nationalities that religion is the only defining identity. Identification with a superior "truth", sometimes embodied in a charismatic leader, swells the vehemence of Ed's dedication to political Islam. "With parental obstacles out of the way, my zeal and commitment to Islamism were unconfined" (p. 47).

The only achievement we wanted was a radical shift in perception, to politicize Muslim public opinion, to connect it as an ummah, as One Nation. Then we could destroy the existing political order in Muslim countries and engage in the conversion or coercion of the rest (Husain, 2007, p. 112).... My daily life was dedicated to activism: recruiting new activists, organizing events, distributing leaflets, arguing and debating with those who opposed us. (p. 129) 


\section{Alienation, the Third Possibility}

\section{A. Edinger's idea}

"With the loss of the god-projection into the church, the individual will at the same time lose his inner connection with the Self. The individual then succumbs to alienation" (Edinger, 1973, p. 65).

\section{B. Definition of alienation}

In the state of alienation, the ego is not only disidentified from the Self, which is desirable, but is also disconnected from it, which is most undesirable. The connection between ego and Self is vitally important to psychic health. It gives foundation, structure and security to the ego and also provides energy, interest, meaning and purpose. When the connection is broken the result is emptiness, despair, meaninglessness and in extreme cases psychosis or suicide. (Edinger, 1973, p. 43)

In summary, an alienated ego is disconnected from the Self, resulting in a sense of emptiness, despair, lack of purpose, and meaninglessness.

\section{Quotations}

Husain becomes disenchanted with Islamism. As a result of his ten years of participation in the Islamist movement, Husain experiences "alienation", a disconnection of his ego-Self axis. Bolen (1982, pp. 98-101) describes the subjective experience of this ego-Self disconnection. It is as if Husain forgot what members of the Hizb ut-Tahrir had told him years before (in 1995): that the Hizb was not a spiritual order but was a political party instead (Husain, 2007, p. 147).

My lethargy towards worship, my distance from God, resulted partly because true faith had not touched my heart in a decade. I wore it on my sleeve, abused it for political ends, but I had lost the essence of Islam: spiritual surrender to serenity. ... Tired of materialism, disillusioned with fanaticism, I had lost my anchor in life. Still, deep down there was a spiritual craving, a yearning for something beyond the immediacy of daily existence. ... Yet as I had become more active in the Hizb, my inner consciousness of God had hit an all-time low. The presence of God in my life, a gift from my parents to me, was lost. ... Despite huge political success, I despised myself for appearing pious and upright in Muslim eyes when all the while I knew that there was a vacuum in my soul where God should be. (Husain, 2007, p. 147)

\section{Re-Connecting the Ego-Self Axis, the Fourth Possibility}

\section{A. Edinger's idea}

He may discover the lost value, the god-image, within the psyche... The connection between ego and Self is now consciously realized. In this case the loss of a religious projection has served a salutary purpose; it has been the stimulus which leads to the development of an individuated personality. (Edinger, 1973, p. 68)

\section{B. Definition of ego-Self axis}

"The ego-Self axis represents the vital connection between ego and Self that must be relatively intact if the ego is to survive stress and grow. This axis is the gateway or path of communication between the conscious personality and the archetypal psyche" (Edinger, 1973, p. 38). In short, the ego-Self axis is the path of communication 
between the ego and the archetypal psyche that enables the conscious personality to remain resilient and to develop.

\section{Quotations}

Husain finds spirituality through the writings of Sufi Islam. He experiences the numinosity of a Sufi holy man in Turkey. This, according to Jung, enhances a religious attitude in the psyche, something essential to individuation. He re-establishes an ego-Self connection.

Sufi-oriented scholars helped me anchor my soul after five years of political Islamism, a shallow, angerridden, aggression-fuelled form of political belief, based on exploiting Islam's adherents but remote from Islam's teachings. (Husain, 2007, p. 190)

Husain describes his encounter with Mahmud Effendi, a Turkish Sufi Muslim, outside of Istanbul in a mountain top village. "My moments with him were brief, as he had to return to rest, but I felt an overawing presence in his company. He made me feel pure, clean, and gentle ... Simply to look upon him reduced Faye to tears" (Husain, 2007, p. 193). Husain concludes his search for spiritual Islam with these words:

By the middle of 2001 I was committed to spiritual Islam. ... As the months passed an immense spiritual energy grew within me. I was at peace with myself and the world around me; my soul was tranquil and no amount of pressure caused me stress. ... I felt - I knew - I was closer to God than I had ever been, and the spiritual void I experienced while in Islamism had been filled. (Husain, 2007, p. 198)

\section{Findings and Their Implications}

In this article I have attempted to link Edinger's ideas on the religious function of the psyche to the experience of a British Islamist. Elsewhere, independently of Edinger's approach, I have applied a Jungian theory of the complexes to an analysis of Husain's autobiography (Alschuler, 2011). Both approaches yield a satisfactory fit between theory and evidence.

Let us recall the four alternative possibilities for the individual whose religious institution ceases to carry the projection of the Self. A person who loses a meaningful connection to a religious tradition at the same time loses the inner connection with the Self and experiences what Edinger calls "alienation". A person who takes on himself the qualities associated with a deity falls victim to "inflation". A substitute secular movement, responding to the spiritual needs of the person, acts as an "unconscious religion". The discovery of a new source of spirituality enables a "reconnection of the ego-Self axis". The quotations from Ed Husain describe just these four alternatives that Edinger proposes. These are evidence that Husain's career as an Islamist belongs to the psychology of religious experience.

An unexpected finding emerges from my analysis of The Islamist. Husain experiences all four possibilities in sequence, his life cycle: adherence to an unconscious religion, followed by inflation, alienation, and a re-connection of the ego-Self axis. Furthermore, the sequence seems to be a "natural" progression. According to Edinger ( $p$. 62), active inflation often leads to a fall, followed by alienation. Then alienation acts as a necessary prelude to awareness of the Self (Edinger, 1973, pp. 48, 52). After an intense alienation experience the ego-Self axis may suddenly break into conscious view (Edinger, 1973, p. 69). Inflation or alienation are dangerous only if either be- 
comes a chronic condition, separated from the psychic life cycle (Edinger, 1973, p. 62): in the phase of inflation there is the danger of fanaticism; when the phase of alienation becomes chronic there is the danger of meaninglessness and suicide (Edinger, 1973, p. 64).

In accordance with Edinger's ideas, Husain's progress from fanatical "reverence" for political Islam (inflation) to Islamic spirituality (reconnection of the ego-Self axis) supports his individuation to some extent, as indicated by my remarks in the "discussion" below. If Husain's transition to moderate Islamism and spiritual Islam can be generalized, then there is room for optimism about the future of Islamism in a world where Islamists would dialog peacefully with those who have contending political views. While my analysis of a single case does not suffice to confirm the existence of a life cycle of an Islamist, the successful application of Edinger's ideas to the autobiography of Ed Husain invites further case studies to explore the notion. I believe that Edinger takes us a long way toward an understanding of how political Islam engages and then disengages its followers. Edinger makes this contribution, amazingly, without ever mentioning political Islam.

\section{Discussion}

\section{Husain's Spiritual Awakening Does Not Equal Individuation}

Many of us, including Edinger, would be pleased that Husain left fanatical Islamism and turned to Islamic spirituality. However, even the numinous spiritual experience that renewed Husain's religiosity, healed his damaged ego-Self axis, and made some of this axis conscious does not make him highly individuated. Why not? One of the essential qualities of the individuated person is the ability to reconcile conflicting tendencies in the psyche, especially those in the unconscious with those in consciousness, by making the former as conscious as possible. Husain has come far but fails to reconcile his "fanatical Islamism" with his "spiritual Islam". As an Islamist, he deprecated the traditional and spiritual Muslims, calling them "partial" Muslims, while reserving for himself the title of "true" Muslim, one who adheres vehemently to the Islamist ideology and empathisizes with oppressed Muslims everywhere. At that time it is probable that Husain's own spirituality was repressed into the unconscious and projected onto the "partial" Muslims, indeed, making them the enemy. Later, when Husain found his Islamic spirituality, the tables turned. He became what he had formerly condemned, namely, a "partial" Muslim. He found nothing to salvage from his previous identity as a "true" Muslim, a fanatical Islamist. His total condemnation of Islamism, for its many half-truths that he discovered, suggests a repression of that Islamist identity including his enthusiastic humanitarian solidarity with oppressed Muslims in the world. Husain threw out the baby (humanitarian enthusiasm) with the bathwater (Islamist ideology). I consider Husain's individuation to be limited by his inability to reconcile his now unconscious Islamist identity with his new spiritual Islamic consciousness. Along these lines I have argued elsewhere that the development of Husain's political consciousness also fails to reach the highest stage (Alschuler, 2011). The Common Ingroup Identity Model (Gaertner, Dovidio, Anastasio, Bachman, \& Rust, 1993) would arrive at a similar conclusion. The authors find that intergroup bias can be reduced by recategorization. In place of one's identification with an in-group opposed to an out-group, one can conceive of oneself as being part of both groups, a more inclusive identity. Husain changed his identity from a "partial" to a "true" and back to a "partial" Muslim, never adopting a more inclusive identity. 


\section{Validity and Reliability of Autobiographies}

In testimonial narratives, reliability refers to the correspondence between the original document and a translation of it; between an oral account to an anthropologist, for example, and the edited version (Frankfort-Nachmias \& Nachmias, 2007, chapter 7). Since neither of these apply to Husain's own writing that is without editing by another person, reliability is not an issue. At issue is the validity of his autobiography. Validity concerns the correspondance between Husain's account of the facts, subjective (feelings, judgments) or objective (events, persons), and some other observer's account of the facts. Support for the validity of Husain's account comes from his frankness in revealing many unflattering descriptions of himself, something that one would not expect to find in a favorably distorted version (invalid) of the facts. In the absence of my own independent observations of Husain's personal experience, I can at most examine the critical comments in the media about his book, The Islamist. The media attention is overwhelming. After a cursory reading of many published reviews, I found a minority with negative comments. These found fault either with his historical facts, his understanding of Islamist ideology, or his interpretations of Islamic scripture. None doubted Husain's sincerity and honesty in recounting his own experiences, evidence in support of its validity.

\section{Limitations of Single Case Studies}

Single case studies are common in psychology and political science, especially in my own field of comparative politics, where the nation is usually a case. In the publications by Jungian analysts, case studies of individuals are the rule rather than the exception. In fact, one of Jung's most noted books, Symbols of Transformation (1956), is the study of a single case. Authors of case studies of individuals often seem to aim toward the generalization of their conclusions, whether or not they take into consideration the issues of reliability and validity.

Valid generalization of the results from a single case study of an individual depends on a number of preconditions, including the possibility of replicating the results in comparable cases. My single case study has Edinger's explicit conceptual and theoretical framework that may be applied to other autobiographies, rendering them comparable. The application of Edinger's framework to comparable cases could be the task of future research. One candidate is the autobiography of Maajid Nawaz. Like Husain, he is also a British-born Muslim once a member of the Hizb ut-Tahrir in London (Nawaz, 2013). In contrast to comparable case studies, a descriptive monograph without a theoretical framework makes replication problematic. Elsewhere I have followed the research strategy of comparable case studies, allowing for provisional generalization from only four cases (Alschuler, 2007).

\section{Causality and Rival Hypotheses}

Philosophers of science consider causal relationships to be unprovable. They argue that one proceeds by eliminating rival hypotheses, the principle of falsifiability, in order to retain that which resists disconfirmation (Blalock, 1972, chapter 1). Yet, in the social sciences we are in the habit of hypothesizing causal relationships. In that tradition, I have implied that the failure of Islam as an institution to respond to Husain's spiritual needs "caused" him to participate in the Islamist political movement as an "unconscious religion". Similarly, I have implied that the failure of this religious institution "causes" three other alternative consequences for Husain: inflation, alienation, and a reconnection of his ego-Self axis. Edinger fails, however, to hypothesize about the intervening conditions that bring about one, rather than another, of these alternative consequences. Even though Husain's experience supports Edinger's causal relationships, this cannot in itself be taken as confirmation. Why not? Participation in the Islamist political movement, for example, has many rival explanations such as the appeal of Islamist ideology and the charismatic quality of its leadership. These are plausible rival hypotheses competing with that of Edinger, 
not taken into account in this case study. Imagine Copernicus and Ptolemy sitting together viewing the sunset. To explain what they observe each one would have a rival hypothesis: a heliocentric and a geocentric one. I would hope to be in the enviable role of Copernicus in my explanation of Husain's experience... but who knows?

Using a variety of theoretical approaches, a number of published studies of Islamism and terrorism contain rival hypotheses that could be relevant to the study of Husain's autobiography. Here are just a few. A Jungian approach applies the theory of complexes to Husain's autobiography (Alschuler, 2011). Victoroff (2005) provides an overview of psychological approaches to the study of terrorists. Moghaddam, Warren, and Love (2013) apply a "staircase to terrorism" approach that takes religion into account. In an earlier article, Moghaddam (2005) uses the "staircase" as a metaphor, rather than a testable model, to explore the gradual transformation of perceived grievances through five floors to acts of terrorism. His second floor to fourth floors resemble Husain's phases of unconscious religion and inflation-fanaticism. On floor two, perceived injustices lead one to identify an enemy, on floor three, to join a terrorist organization, and on floor four, to discriminate between "us and them". At each higher floor the perceived options become fewer until on the fifth floor, terrorist acts stand as the only option. This approach could remedy the absence of explanations by Edinger for the transition between the alternative consequences of a loss of faith. The staircase metaphor would guide the search in Husain's autobiography for the conditions that moved Husain from floor two to four, then opened an exit door before reaching the fifth floor.

\section{Conclusion}

The religious function of the psyche, as described by Edinger (1973), goes a long way in clarifying the experience of a young British Islamist, Ed Husain. His life cycle, in some ways, ties in to the Common Ingroup Identity Model (Gaertner et al., 1993) and the staircase to terrorism approach (Moghaddam, 2005). All this suggests that Jungian psychology could be part of a multidisciplinary study of political movements.

\section{Funding}

The author has no funding to report.

\section{Competing Interests}

The author has declared that no competing interests exist.

\section{Acknowledgments}

The author has no support to report.

\section{References}

Alschuler, L. (2007). The psychopolitics of liberation: Political consciousness from a Jungian perspective. New York, NY: Palgrave Macmillan.

Alschuler, L. (2009). Fanaticism: A psychopolitical analysis. Spring, 81, 59-83. 
Alschuler, L. (2011). Islamism and fanaticism: A Jungian psychopolitical analysis. Psychotherapy and Politics International, 9(2), 134-152. doi:10.1002/ppi.240

Aslan, R. (2010). Beyond fundamentalism: Confronting religious extremism in the age of globalization. New York, NY: Random House.

Blalock, H. (1972). Causal inferences in non-experimental research. New York, NY: Norton.

Bolen, J. S. (1982). The tao of psychology: Synchronicity and the self. San Francisco, CA: Harper and Row.

Edinger, E. (1973). Ego and archetype: Individuation and the religious function of the psyche. New York, NY: Penguin.

Frankfort-Nachmias, C., \& Nachmias, D. (2007). Research methods in the social sciences. New York, NY: Worth.

Gaertner, S. L., Dovidio, J. F., Anastasio, R. A., Bachman, B. A., \& Rust, M. C. (1993). The common ingroup identity model: Recategorization and the reduction of intergroup bias. European Review of Social Psychology, 4, 1-26.

doi:10.1080/14792779343000004

Husain, E. (2007). The Islamist: Why I joined radical Islam in Britain, what I saw inside and why I left. London, United Kingdom: Penguin.

Jung, C. G. (1938). Psychology and religion. New Haven, CN: Yale University Press.

Jung, C. G. (1956). Symbols of transformation. Princeton, NJ: Princeton University Press.

Jung, C. G. (1968). Psychology and alchemy. Princeton, NJ: Princeton University Press.

Jung, C. G. (1990). The undiscovered self. Princeton, NJ: Princeton University Press.

Moghaddam, F. M. (2005). The staircase to terrorism: A psychological exploration. The American Psychologist, 60(2), 161-169. doi:10.1037/0003-066X.60.2.161

Moghaddam, F. M., Warren, Z., \& Love, K. (2013). Religion and the staircase to terrorism. In R. F. Paloutzian \& C. L. Park (Eds.), Handbook of the psychology of religion and spirituality (2nd ed., pp. 632-648). New York, NY: The Guilford Press.

Nawaz, M. (2013). Radical: My journey out of Islamist extremism to a democratic awakening. London, United Kingdom: WH Allen.

Victoroff, J. (2005). The mind of the terrorist: A review and critique of psychological approaches. The Journal of Conflict Resolution, 49(1), 3-42. doi:10.1177/0022002704272040

von Franz, M.-L. (1985). Projection and re-collection in Jungian psychology: Reflections of the soul. London, United Kingdom: Open Court. 